\title{
Occupying the Blind Spot: the role of Kuripa ngozi in Transitional Justice in Zimbabwe the case of Hwesa Clan
}

\author{
Ched Nyamanhindi \\ PhD student at the Institute of Peace, Leadership and Governance (IPLG) at Africa University \\ DOI: 10.29322/IJSRP.10.12.2020.p10819 \\ http://dx.doi.org/10.29322/IJSRP.10.12.2020.p10819
}

\begin{abstract}
Zimbabwe has a history of many attempts at transitional justice dating back to the 1980s. Healing and reconciliation efforts to address conflicts in Zimbabwe have faced numerous challenges. The Unity According of 1987 mainly addressed the issues of the perpetrator and totally ignored the victim. It was an agreement between leaders of two political parties neglecting to address the majority that had suffered in Matebeleland and Midlands. The Unity accord brought alleviation nation-wide, but in parts of the country where it happened problem remain unsolved and resolved. These include poor health, poverty, practical and legal problems and a deep mistrust of Government.

In the absence of an effective and inclusive transitional justice initiated by the state, communities affected by conflict turn to endogenous mechanisms to address conflict. This paper analyses the traditional method of Kuripa ngozi used by the Hwesa people of Nyanga, Zimbabwe to resolve conflict involving the death of the victim. The family of the perpetrator is asked to pay the victim's family some form of compensation. This is done through the mediation of the dare and the conducting of cleansing ceremonies to appease the spirit of the dead. This paper analyses the process, its advantages and challenges and makes recommendations of making the traditional mechanism better.
\end{abstract}

Index Terms- Transitional justice, traditional mechanism, dares, Kuripa ngozi, culture, reconciliation

\section{INTRODUCTION}

$\mathrm{T}_{\mathrm{i}}^{\mathrm{h}}$ he concept of transitional justice has its roots in the international human rights movement. It was aimed at the use of judicial process to address human rights violations and atrocities committed by repressive regimes. Transitional justice became useful in addressing war crimes and massive human rights abuses committed in violent conflicts (Kritz 1995; Teitel 2000). Transitional justice principles are recognised by the InterAmerican Court, European Court of Human Rights and UN treaty bodies such as the Human Rights Committee. The creation of the International Criminal Court in 1998 was a milestone to show states obligation in fighting impunity and to seek justice for victims of human rights violations (International centre for transitional justice).

According to Kofi Annan former secretary General of the United Nations, Transitional Justice is the full range of processes and mechanisms associated with a society's attempts to come to terms with a legacy of large-scale past abuses, in order to ensure accountability, serve justice and achieve reconciliation. They may include both judicial or non-judicial mechanisms, with differing levels of international involvement (and none at all) and individual prosecutions, reparations, truth-telling, institutional reform, vetting and dismissals or a combination thereof (UN Security Council, 2004).

Transitional justice along the way has extended its importance to include the establishment of tribunals, truth commissions, lustration of state administrations, settlement on reparations, and also political and societal initiatives devoted to fact-finding, reconciliation and cultures of remembrance.

In the African region, as follow up to the June $2006 \mathrm{AU}$ Policy on Post-Conflict Reconstruction and Development, the African Union developed a policy on Transitional Justice. The AU defines Transitional Justice as the various (formal and traditional or non-formal) policy measures and institutional mechanisms that societies, through an inclusive consultative process, adopt in order to overcome past violations, divisions and inequalities and to create conditions for both security and democratic and socioeconomic transformation-AU TJ Policy. The policy emphasises that TJ is not new to Africa. Africa has varied experiences in TJ but there is no one, comprehensive policy framework to guide and promote experience sharing among Member States. Based on this, the report proposed developing a policy on $\mathrm{TJ}$ for adoption by the relevant AU organs that is home-grown, unique to Africa, rich in its progressive methodologies and approaches, and rooted in African shared values, traditional justice systems and experiences.

Machakanja (2010) reiterates that, "Zimbabwe has been trapped in a complex and protracted political crisis that has seen rising levels of human-rights violations, including kidnappings, disappearances, arbitrary detentions, torture, sexual violence and the forced recruitment of youth by armed groups, to name just a few." There have been attempts at TJ by the Zimbabwe government through amnesties, presidential pardons and unity accords between major contesting political parties. Zimbabwe also put in place through its 2013 Constitution a National Peace and Reconciliation Commission (NPRC) to address Transitional Justice issues affecting the country. However, the government is viewed as unwilling to engage honestly and genuinely with the past as some of the senior government officials are implicated in the atrocities. The oratory of unity based on amnesia has been given precedence over the real mechanisms that promote peace building and reconciliation. Indemnities, amnesties and presidential pardons have been used to protect perpetrators of conflict and violence at the expense of justice (Benyera and Ndlovu-Gatsheni, 2015). Of note in Zimbabwe, is the absence of traditional methods of Transitional Justice in the quest to build 
sustainable peace in the country. Traditional methods of TJ in Zimbabwe such as Kuripa ngozi have been relegated to the sidelines whilst the government tries to implement TJ through western methods. This paper argues that traditional methods of TJ in Zimbabwe should be taken from the blind spot where they are currently placed and given prominence side by side with the western methods for effective and sustainable Transitional Justice.

\section{CONTEXT AND Methodology}

The study was carried out in Nyanga, Zimbabwe. Nyanga is situated in the Eastern part of Zimbabwe close to the Mozambique border. Using the case study approach, the researcher carried out an in-depth and multi-faceted exploration of the Kuripa ngozi method in their real-life settings of the Hwesa Clan. The Hwesa clan is domiciled in a remote area where access to modern justice system is difficult due to factors such as proximity and costs. Therefore the use of traditional justice mechanisms to settle disputes is highly prevalent and trusted. The respect for culture and traditional institutions is deep. The researcher carried out indepth interviews with Headman Sanyamuera Dare to gain an understanding of the traditional method of Kuripa ngozi and how it is carried out by the Hwesa. The case of Moses Mupezeni who was murdered and the Kuripa ngozi method was used to settle the dispute were analysed. Face to face interviews with community members, Svikiro and victims' families were carried out. The use of the case study approach ensured that the Kuripa ngozi phenomenon is analysed in depth and in its natural context. The uniqueness of the Kuripa ngozi approach is thus brought out and recommendations to improve it proposed.

\section{THEORIES OF TRANSITIONAL JUSTICE}

Transitional Justice is a subject area that is highly undertheorised. Although there have been activities conducted globally and the reverberant academic debate on the topic, there are few attempts to conceptualise transitional justice theoretically (Susanne Buckley-Zistel, Teresa Koloma Beck, Christian Braun and Friederike Mieth,2014).

Transitional Justice discourse and practice are largely based on Western thinking that is strongly influenced and shaped by historical experiences. The events and experiences that have influenced the development of Transitional Justice include the Nuremberg and Tokyo trials after the Second World War, the change from dictatorship to democracy in South America, international criminal tribunals in the former Yugoslavia and Rwanda, and the Truth and Reconciliation Commission (TRC) in South Africa. There have been attempts to theorise Transitional Justice with the focus on justice and transition. Catherine O' Burke (2013) assesses what a transition should achieve, the type of society that must be birthed, how a transition can be accomplished and how gendered citizenship can be achieved after a transition. Aiken (2013) argues that the aim of a transition is the transformation of the antagonistic relationships between the parties to the conflict through transitional justice leading to reconciliation. Other scholars advance the view that transitional should lead towards liberal values and democracy (Teitel 2003;
Mihr 2012). For Oomen (2005) the rule of law remains a paramount objective in the transitional processes.

Scholars that lean on the notion of justice outline different understandings of the matter. Justice is viewed as punitive, corrective, restorative, reparative or distributive. Lambourne (2009) discusses the linkages between the different types of justice for example retributive, restorative and distributive justice. Justice is views as aiming to promote just peace and protecting human rights (Mani 2002).Efforts to theorise Justice have also focused on the inclusion of economic, social and cultural rights in addition to political and civil rights (Laplante 2008; Mani 2008).

Theoretical this paper challenges the notion that Transitional Justice is a global norm. Nagy (2008) suggests that Transitional Justice can be perceived from a local situation.The concepts of justice, truth and reconciliation can mean different things to different people and societies. By looking at the traditional method of Kuripa Ngozi as practised by the Hwesa Clan it is clear that the process and components of Transitional Justice are different from the Western perspective.

Thus the need to look at traditional methods of transitional justice in Africa and how they add value to the theoretical framework of the transitional justice discourse. The method of Kuripa Ngozi underpins the theory that Transitional justice must be encompass both the victim and perpetrator and their participation in the process is vital to sustainable peace.

\section{The Western versus Traditional Methods Contestation}

Western methods of TJ include Retributive justice and the rule of law. Criminal courts are the main instruments of this method. Courts are formed to administer penal justice by holding accountable those who committed atrocities and other punishable acts. It acknowledges the suffering of the survivors and by establishing a record of the past misdeeds can be seen as the first step in the process of healing the societal and the individual trauma (Kasapas, 2008). However, critics of retributive justice argue that it focuses on punishing the perpetrators and cannot heal the trauma of the victims. The counts become "combative encounters" that fail to promote the revelation of truth (De Brito, 2010). Another method is Restorative Justice where the focus is on Reconciliation and forgiveness, through a mending process that requires the active participation of the community. The main focus however, is on the victims and the involvement of the offenders. Truth commissions are part of restorative justice- aim to promote truth telling and allow the victims to express their feelings (Brahm, 2007). TCs have received severe criticism because they do not possess the authority to allocate legal punishment or reparations. Their role is restricted to suggestions which can be ignored by the political leadership whether because the new regime lacks the resources to implement the outcomes (Dukalskis, 2011)

According to Mani (2002) Distributive justice aims to "tackle the roots of the unrest" by addressing the structural factors that led to the escalation of conflict to violence. Dealing with injustice and inequality during the reconstruction phase, is really important in order to ensure sustainable peace and reconciliation. Thiessen states that reparations are the key element of distributive justice to rectify past wrongs, restore property or rights and provide compensation, rehabilitation and satisfaction to the victims. However, reparations whether material or symbolic, 
cannot totally compensate the victims for the loss and the trauma that was inflicted upon them. Reparations focus exclusively on the past while reconciliation is forward looking. (Kasapas, 2008)

Many of the conflicts that occurred in Africa in the 1990s were approached with a wide range of Western approaches and mechanisms to regulate and resolve them. Approaches such as the use of international statesmen, international and regional organizations, the involvement of neighboring countries, peace support operations and civil society organizations (CSOs) (Galadima, 2006). Bukari (2013) argues that these methods of conflict resolution were western and conventional and did not take into account the cultural milieu of their occurrence. As a result, many of the conflicts became protracted and intractable. Even where there is a return to peace, deep-seated issues still remain to be resolved and therefore make peace in these areas fragile. Scholars like Bukari have thus questioned the effectiveness of most of these conventional and western resolution approaches and mechanisms in Africa. Traditional mechanisms of conflict resolution in Africa have many times been sidelined at the expense of Western mechanisms. Bukari reiterates that the conflicts in Somalia, Sudan, Democratic Republic of Congo and Niger Delta rage on, despite efforts to resolve them. The challenges associated with the resolution approaches call for alternative resolution mechanisms to bring peace to the African continent (Bukari, 2013). Boege (2006) therefore argues that the intervention approaches to these conflicts will need traditional/indigenous methods to resolving them. A fusion of non-state traditional actors and methods (indigenous) and their combination with Western forms of conflict transformation can be an effective method of TJ in Africa.

Scholars such as Huyse (2008) highlight the weaknesses of traditional methods of TJ. Traditional approaches to conflict resolution are usually lumped together, regardless of geographical location and structure. There is a tendency emerging literature on traditional approaches to mystify or "romanticize" these approaches as being more "authentic", "effective" and "homegrown" while overlooking their limitations (Huyse, 2008). Working with traditional authorities also became appealing to Western audiences as it allowed them to base their "legitimacy on claims to represent and work with authentic African identity and difference, treat Africans with dignity as Africans and avoid imposing Western ideas and models" (Branch, 2017).

Traditional approaches have a weakness of being based on hierarchical or patriarchal systems which are intrinsically exclusive. These Systems exclude the voices of women or youth thereby posing a danger of excluding their views in any $\mathrm{TJ}$ process. Branch (2017) supports this view by arguing that the use of traditional methods in northern Uganda among the Acholi people has had the perverse effect of reinforcing the forms of domination and inequality in society that partially led to the conflict in the first place. Mutisi (2012) notes that while "traditional institutions are rooted in the culture and history of African societies, the modern state exerts a large amount of influence on these institutions.... In some cases the traditional institutions are politicized and have become instruments of propagating state ideology." The politicized involvement of the state in traditional methods of TJ can negate the peace process.

As noted by the International centre for transitional justice "transitional justice should include several measures that complement one another. For no single measure is as effective on its own as when combined with the others". In every society coming out of conflict there are differences in context, history, interests and parties involved. The decision on which methods of TJ to use depends on several factors including the depth and intensity of the conflict.

\section{UN GUIDING PRINCIPLES ON TRADITIONAL MECHANISMS}

The success of the Gacaca courts in Rwanda according to Huyse (2008) led to the positive recognition of traditional approaches in the framework of transitional justice and reconciliation policies. It was reflected by the UN's recognition of traditional mechanisms and their critical role in administering justice and settling disputes. The Secretary General Report on the Rule of Law and Transitional Justice in Conflict and Post-Conflict Societies (2004) notes that "due regard must be given to indigenous and informal traditions for administering justice or settling disputes, to help them to continue their often vital role and to do so in conformity with both international standards and local tradition" Whilst acknowledging the significance of traditional methods in TJ, the UN was fully aware of the gaps posed by their use without international guidelines. The following guidelines were thus put in place by the UN as its approach to the use of traditional methods in TJ:

1. Support and actively encourage compliance with international norms and standards by transitional justice processes and mechanisms. Traditional mechanisms of TJ must be in sync with the modern international legal system: international human rights law, international humanitarian law, international criminal law, and international refugee law

2. Strive to ensure women's rights through transitional justice processes and mechanisms. They should pay special attention to abuses committed against groups most affected by conflict, particularly women. Gender inequality is one of the most pervasive forms of societal inequality and is often exacerbated by conflict and situations of gross human rights violations.

3. Support a child-sensitive approach to transitional justice processes and mechanisms. Children are among those most affected by violence and armed conflict. Traditional methods of TJ should enhance the protection of children and prosecute offenders of crimes against children. Child soldiers should first and foremost be treated as victims not only as offenders.

4. Encourage a comprehensive approach integrating an appropriate combination of transitional justice processes and mechanisms. The fusion of judicial and non-judicial processes and measures, including truth seeking, prosecution initiatives, reparations programmes, institutional reform or a combination of these in $\mathrm{TJ}$ processes.

The recognition of Traditional methods of TJ by the United Nations is an important milestone for traditional approaches in the discourse of TJ. Like any other TJ approach, traditional methods have aspects which require improvement. Traditional methods of TJ should be removed from the shadows and blind spots of transitional justice mechanisms and take a prominent role in the Transitional Justice discourse.

\section{Traditional methods of TJ in Africa}


Traditional methods of TJ have been used in Africa with different levels of success depending on the context. Since 1986 Uganda has experienced a costly and brutal civil war. The high cost of an unending civil war has caused Ugandans to re-assess the approaches of resolving conflict. For the Acholi of Northern Uganda the bitter experience of unending conflict has generated a commitment to reconciliation and peaceful settlement of conflict rather than calling for retributive justice (Afako, 2013). In the Ugandan context the communities facing the brunt of civil war see the advantages of using the traditional approaches rather than the retributive approach.

The rwodi-traditional chiefs oversee the mediation process called mato oput which many Acholi believe brings forgiveness and reconciliation in a way that formal justice system cannot. It's a family and clan centered reconciliation where acknowledgement of wrong, acceptance of compensation, and the sharing of a symbolic drink. The Mato Oput has been supported by NGOs, churches and government in the quest to promote transitional justice in Uganda. The process involves former Lord Resistance Army (LRA) combatants who are usually the perpetrators and victims from the community. Individual cleansing ceremonies also take place when an LRA combatant returns forging the way for reconciliation and reintegration. The use of the Mato Oput in Uganda has proven that the complexity of conflict, its duration, effects, and inability of formal processes to address serious violations has led to the renewal of traditional methods of $\mathrm{TJ}$ (Afako, 2013).

After the civil war in Liberia, the Truth and Reconciliation Commission recommended the use of the traditional method of the Palava Hut transitional justice mechanism. It was used to redress, atone for, heal, and resolve community conflicts left in the wake of the civil war (Ministry of Internal Affairs 2012). In Rwanda the use of the abunzi mediators is critical for conflict resolution. According to Mutisi (2011) these institutions have presided over cases such as land disputes, civil disputes and, in some instances, criminal cases. In Rwanda, these traditional institutions of dispute resolution are fully recognised under the law. Further Mutisi argues that as "Africa continues to develop and strengthen its political institutions for conflict resolution, the place of traditional institutions attracts the attention of practitioners and policy makers. There are emerging synergies between traditional and modern institutions of conflict resolution". The use of traditional methods in TJ on the African continent is work in progress which is proving to be critical in the quest for justice and sustainable peace. Endogenous approaches to TJ should not be sidelined but rather strengthened to address the numerous conflicts on the continent.

\section{An overview of Transitional Justice in Zimbabwe}

Since Zimbabwe's independence in 1980, the issue of achieving sustainable peace and development has remained a challenge due to a lack of comprehensive approaches to issues of transitional justice. The political events and conflicts in Zimbabwe have created challenges that have drawn the attention of both domestic and international actors (Machakanja, 2010). Zimbabwe needs a transitional justice system and process that would guarantee maximum accountability for the committed atrocities with a view to facilitating sustainable national healing and just peace. The argument for a just transitional process is premised on the argument that families and relatives of those who disappeared need to know what happened to their loved ones and have a sense of who is responsible (Machakanja, 2010)

Machakanja (2010) argues that it is generally agreed that the policy of National Reconciliation, as espoused after independence, lacked practical substance, since it did not seek to address the abuses that occurred before 1980 in a structured and comprehensive way. The Unity According of 1987 mainly addressed the issues of the perpetrator and totally ignored the victim. It was an agreement between leaders of two political parties neglecting to address the majority that had suffered in Matebeleland and Midlands (Ndlovu-Gatsheni, 2012). The 2013 Constitution created the National Peace and Reconciliation Commission which was tasked to spearhead TJ in Zimbabwe. However, the Commission is underfunded and has done very little on the ground to address the grievances suffered by victims.

The National Transitional Justice Working Group (NTJWG) is a platform established by forty-six Zimbabwean transitional justice stakeholders to push the TJ agenda in Zimbabwe. The NTJWG work is based on the principles of victim centeredness, inclusiveness, truth, justice, compensation, reparations, healing, reconciliation and never- again. The current transitional justice discourse in Zimbabwe is a top to bottom approach where the state is dictating the process with little input from other stakeholders.

According to Sanchez, (2019) the Zimbabwean context presents challenges as it significantly depart from the conventional TJ conceptualisation. No meaningful transition has taken place and some of the alleged perpetrators of human rights violations hold prominent offices in the government.

The several attempts at Transitional Justice in Zimbabwe point to a neglect of traditional approaches as alternative to the Western methods that have failed to yield results on the ground. Zimbabwe has traditional approaches such as dare and Kuripa ngozi which if utilized can result in sustainable peace and development in the country.

\section{Kuripa ngozi as a traditional method of conflict resolution in Zimbabwe}

Kuripa ngozi is a traditional method of conflict resolution that is common and prevalent in all African cultures in Zimbabwe. It is practiced by all the main indigenous African groups in the country. In the Ndebele culture it is called" kuhlaura ingozi". The Ndau speaking people call it "kuripe ngozi". In Tonga it is referred to as "kuliya muzimu". In kalanga it's called "Tshigumba tshenha". In Nambya they call it "Kulipa ndandu weNgonzi". The process of Kuripa ngozi has similar characteristics in all the different cultures where it is used as a transitional justice mechanism. There are element of truth telling, compensation, reconciliation and accountability in the Kuripa ngozi method.

All these cultures believe that if a person is murdered his spirit will seek vengeance in the family of the murderer "ngozi". The spirit will cause misfortunes and deaths in the family of the perpetrators to a point where they consult spirit mediums and traditional leaders for mediation. According to Chivasa (2018) the traditional practice of Kuripa ngozi has proved valuable in terms of its capacity to resolve conflict, re-create social relationships that have been distressed by violent conflict at the family level. $\mathrm{He}$ further highlights that it has the "propensity to promote inclusivity 
of both men and women and constructive engagement in resolving inter-family murder-related conflict" The approach has the capacity to deliver accountability and compensation as conditions for reconciliation. The process of Kuripa ngozi was meant to restore the lost life in the family of the deceased and to unite the two families through bloodline (marriage and children that will be born). It accounted for truth and justice for the victims and reunites the divided parties (Simura \& Mudimu, 2019).

Kuripa ngozi is viewed as the primary traditional transitional justice mechanism mostly in the rural areas of Zimbabwe. This is due to its capacity to deliver on key transitional justice deliverables such as accountability and compensation (Chavunduka, 1994; Goldin and Gelfand, 1975). Kasambala (2009) argues that transitional justice in Zimbabwe is characterized by the absence of the rule of law and run by partisan state institutions such as the courts, police and army. Accessing justice becomes almost impossible for victims. Under this status quo, victims turn to traditional forms of transitional justice as the most feasible alternative for them to get justice and reconciliation. One prominent case where a victim's family turned to traditional justice mechanisms when they were let down by the state institutions is that of Moses Chokuda a victim of political violence. Chokuda was murdered by four Zanu PF supporters including Farai Machaya the son of Jason Machaya who was a Provincial Governor. Chokuda's body was not buried for 31 months as he avenging spirit caused misfortune to his murders. He was finally buried after the Kuripa ngozi process was done. The murderer's family paid 35 cattle and 15000 United States dollars to the victim's family (Newsday 2011/02/04).

Despite, being tried and tested as a traditional method of transitional justice, Kuripa ngozi remains in the blind spot of TJ in Zimbabwe. There is no legislation in Zimbabwe that recognises the method as central to transitional justice. Countries such as Rwanda have enacted laws that recognise traditional methods such as Gacaca courts and Abunzi as part of the justice system (Mutisi, 2011). The National Peace and Reconciliation Commission in Zimbabwe is silent about the role that traditional mechanisms such as Kuripa ngozi can play in peace and reconciliation. Rather Western methods have been given prominence whilst traditional methods have been sidelined. Over a long period of time Kuripa ngozi has been the main traditional method of transitional justice and must be incorporated by the NPRC as part and parcel of TJ package.

\section{Kuripa ngozi: the case of the Hwesa Clan}

The Hwesa people of Nyanga, Zimbabwe believe that when a person is killed his or her spirit will seek justice by causing misfortunes in the family of the perpetrator through as an avenging spirit called "ngozi" in Shona. The family of the perpetrators experience misfortunes such as illness, one death after another and series of mental illness. These will force the family to consult a "Svikiro" or Spirit Medium looking for a solution. The Headman gave an example of one such case where Moses Mupezeni who was a known supporter of the opposition Movement for Democratic Change (MDC) was murdered in June 2008. Mupezeni was beaten to death by 14 youths who were sent by a ZANU PF leader in the area. Mupezeni family refused to take part in the funeral forcing the chief to bury his body. The killers were arrested and sent to jail but they returned after less than two months. The Headmen sighted this as a failure of Western methods to bring justice to victims of political violence. Impunity and corruption in the justice system in Zimbabwe force victims to seek for justice in the traditional approaches. The Kuripa ngozi method in the Hwesa clan is done in the following stages:

\section{THE USE OF DARE}

The Dare is a customary court in Zimbabwe, which is made used for conflict resolution among the Shona people. Criminal and civil cases are tried in the presence of community members and a ruling is arrived at after consultations. In the case of the Sanyamuera of the Hwesa clan the Dare is made up of 7 "makurukotas" officials who are chosen from the community. The current dare consists of 5 men and 2 women of mixed ages. Gender and age representation in the dare is important to provide a fair hearing to women and men and the old and young. The Makurukotas are chosen on the bases of their experiences of life and their "Hunhu" character in the community. The officials of the Dare are chosen by the whole community. The Dare have evolved over the years to accommodate roles such as secretary and treasurer to record the Dare proceedings and the treasurer to oversee the payment of penalties. The positions in the Dare include the secretary whose role is to document all the cases that are handled by the court. Mupurisa vaMambo's role is to enforce the judgments' of the court. The treasurer is responsible for collecting the penalties from the offenders. Elders from the chief's family are also part of the Dare. The Dare is held on the Friday of every week if there are cases for trial. The Dare of Headmen Sanyamuera has presided over transitional justice cases in the area using traditional approaches such as Kuripa ngozi. The cases tried at the Dare include murder cases resulting from political violence during the 2008 Presidential Runoff in Zimbabwe and other cases which have resulted in "ngozi" avenging spirit affecting the family of the perpetrators. Headman Sanyamuera and his Dare have used the traditional methods within their culture to resolve conflict and promote transitional justice.

\section{Stage One}

After the murder of a person, the ngozi/ avenging spirit of the murdered person causes misfortunes in the family of the perpetrators forcing them to seek help from the Chief who advises them to seek help from a Svikiro residing in the area.

\section{Stage two}

With the help of the Svikiro, a traditional ceremony is held where beer is brewed in the bush by older women. The spirit of the murdered person then speaks through the Svikiro in the presence of the Headman and his Dare and the family of the perpetrators. It has to give an accurate account of what happened, when it happened, where it happened and what it wants as compensation. In the case of murdered Mupezeni, the aggrieved spirit demanded that the families of the people involved in his murder should pay compensation in the form of cattle.

\section{Stage three}

The Headman and the Dare become mediators between the perpetrators family and the victim's family. The role of the dare is to bring the families together for dialogue to discuss the way 
forward and the payment of the compensation as narrated by the Svikiro. The victim's family is approached and appraised that the perpetrators family want to pay compensation/Kuripa ngozi for the death of their relative. Misunderstandings may arise between the two families and the Dare must mediate until common ground is reached and the conditions for compensation are set.

\section{Stage four}

The family of the perpetrator pays compensation to the victim's family at the Dare in the presence of the whole community, the affected families and the Svikiro. The compensation that is paid must be the exact items as demanded by the avenging spirit through the Svikiro. If this is not done according to the said demands the misfortunes will continue to affect the perpetrator's family. One of the demands of the contested demands of the avenging spirit is that a virgin girl be given to the victim's family as compensation. This has been criminalised under Zimbabwean law as it infringes on the rights and protection of children. However, the practice is still going on at family and community level. It becomes a criminal offence when a child is forced to go to the victim's family but in cases where there is mutual agreement the practice is prevalent.

\section{Stage Five}

Through the Svikiro the spirit of the murdered person is asked if it is satisfied in the presence of the whole community. If the avenging spirit is satisfied and all the affected families confirm that they are satisfied then the reconciling process is set in motion. A "kuchenesa"/cleansing ceremony is then held. Water is poured on the perpetrators family by a member of the victim's as symbol that they have been cleansed. The people participating in the ceremony will clap hands and ululate in celebration.

\section{Stage six}

The perpetrator's family gives the dare a "konde"/token of appreciation in the form of a goat and the Svikiro is given a cow as a payment for its role in the Kuripa ngozi process. This is a way of respecting the Dare and the Svikiro in the roles they play in the reconciliation process.

\section{Stage Seven}

The Headmen and the Dare then provide counseling to both families. The Headman's message will emphasise peace between the two families and that reconciliation is important. This is an important stage of the process as the community leaders use the platform to advise the community on the vices of violence and the benefits of peace. Community members are taught to use non violent means to resolve conflict and to live in harmony. The misfortunes that the perpetrator's family experienced and the compensation that they pay serve as deterrent and a lesson to the whole community. The two families then exchange "pfekamutenga"/peace token in the form of chickens to show the Dare and the community that they have reconciled. From then on the two families are expected to live in peace and the spirit of the victim will cease to cause misfortunes in the perpetrators' family.

\section{The Advantages of Kuripa ngozi as a transitional justice mechanism}

The Kuripa ngozi has several advantages as TJ mechanism. The family of the victim directly benefits from the compensation paid by the perpetrator's family unlike in cases where the criminal and retributive approaches are used. The state benefits and the family of the victim lose out. When using the traditional method of Kuripa ngozi the victim's family benefits from the compensation usually in the form of cattle and goats.

The approach is transparent and has elements of integrity and accountability unlike the modern forms of Transitional justice in Zimbabwe where the state can interfere in the delivery of justice. There are known perpetrators of human rights violations who have never been brought to justice due to corruption and political meddling in the justice system. The ngozi approach brings all perpetrators to justice without fear or favour.

Kuripa ngozi preserves the African culture's belief in the importance and sanctity of human life. The payment of compensation ensures that the sanctity of human life is respected and the right to life protected

Communities learn from the misfortunes of ngozi that killing people does not pay. The right to life is therefore respected. The process of Kuripa ngozi promotes dialogue and healing between the families of the victims and the perpetrator. Conflict resolution is achieved and reconciliation is promoted.

Counseling and peace education is provided by the traditional leader throughout the processes helping the perpetrator, victim's family and the community to appreciate peace and reconciliation.

The approach is cheap compared to western approaches. It makes use of community resources and ensures the involvement and participation of the whole community.

\section{The Disadvantages of Kuripa ngozi}

The people that suffer the consequences of ngozi and pay the compensation are usually not the perpetrators themselves but members of the family. Hence people who may not have committed the crime are caught in the web of misfortunes and end up paying for crimes they did not commit.

In some cases compensation is demanded in the form of a virgin girl which is a gross human rights violation and a crime.

The method is relevant and functional in a specific cultural and religious context. It cannot be used in other cultures and religion e.g. English, Indian

\section{Lessons from the Hwesa Case}

Kuripa ngozi method is a community and cultural based method of transitional justice which brings effective healing and reconciliation through community involvement.

The process has elements of transparency, accountability and integrity making the method an effective tool of justice

When victims' view the state's attempts to justice as skewed they turn to traditional methods such as Kuripa ngozi for redress.

One method of transitional justice may not be enough to achieve justice for the victims. In the case of Moses Mupezeni the perpetrators were given prison sentences but the victim's family turned to the traditional method of Kuripa ngozi to get compensation. A combination of two methods TJ may be required to achieve effective healing and reconciliation. 
Despite being sidelined by the state, the traditional method of Kuripa ngozi has survived overtime and continues to be effective in conflict resolution and reconciliation

The reliance of Kuripa ngozi on the spiritual realm for the compensation to be paid makes the method rigid and inflexible and leaving no room for the living to negotiate for a lesser punishment.

\section{RECOMMENDATIONS}

The government of Zimbabwe should consider enacting laws to adopt Kuripa ngozi as an approach to TJ justice as countries such as Rwanda, Uganda and Liberia has done. This will ensure that the method is practiced within the law and following guidance and standards of international law.

Kuripa ngozi should be adopted as TJ mechanism by the National Peace and Reconciliation (NPRC) which is spearheading the peace and reconciliation process in Zimbabwe.

Training of traditional leaders in the area of human rights to ensure that as they mediate conflicts through Kuripa ngozi, human rights are protected and women and children are not harmed.

Funding should be made available to traditional leaders and the Dare as a community institution to strengthen the delivery of justice.

There is too much variance on the penalty that is given and it depends on what the spirit of the deceased demands. Traditional leaders and Svikiro/Spirit medium should come up with ways of standardizing the penalty.

\section{CONCLUSION}

Although traditional methods of Transitional Justice have been in use in countries such as Rwanda, Sierra Leone and Liberia in Zimbabwe there are still in the blind spot. Despite Zimbabwe's dire need for a functional and inclusive Transitional Justice process traditional methods have been ignored. Western methods of TJ just like traditional methods have weaknesses and calls for the fusion of the two discourses to come up with meaningful TJ. As shown by the use of the Kuripa ngozi approach in the Hwesa Clan of Nyanga, traditional methods offer a participatory and transparent way of conflict resolution. The traditional approach of Kuripa ngozi has its own weaknesses but these can be addressed to ensure that it's operating within the confines of International law. In the form of traditional methods of Transitional Justice, Zimbabwe has an untapped resource. Approaches such as Kuripa ngozi should be taken from the blind spot and thrust on the Transitional Justice trajectory.

\section{REFERENCES}

[1] Afako, B. (2013). Reconciliation and justice: Mato Oput and the amnesty act. ACORD 64-67.

[2] Aiken, N. T. (2013). Rethinking reconciliation in divided societies. Transitional Justice Theories, 40.

[3] Annan, K. (2004). The Rule of Law and Transitional Justice in conflict and post-conflict societies: Report of the Secretary General. New York: United Nations Security Council.

[4] Awedoba, A. K. (2014). An Ethnographic Study of Northern Ghanaian Conflicts: Towards a Sustainable Peace: Key Aspects of Past, Present and Impending Conflicts in Northern Ghana and the Mechanisms for Their Address (No. 3). African Books Collective.
[5] Barahona de Brito, A. (2010). Transitional justice and memory: Exploring perspectives. South European Society and Politics, 15(3), 359-376.

[6] Boege, V. (2006). Traditional approaches to conflict transformation: Potentials and limits.

[7] Brahm, E. (2007). Uncovering the truth: Examining truth commission success and impact. International Studies Perspectives, 8(1), 16-35.

[8] Branch, J. (2017). Territorial Conflict in the Digital Age: Mapping Technologies and Negotiation. International Studies Quarterly, 61(3), 557569.

[9] Buckley-Zistel, S., Beck, T. K., Braun, C., \& Mieth, F. (Eds.). (2013). Transitional justice theories. Routledge.

[10] Bukari, K. N. (2013). Exploring indigenous approaches to conflict resolution: The Case of the Bawku Conflict in Ghana. Journal of Sociological Research, $4(2), 86-104$.

[11] Chivasa, N. (2019). Kuripa Ngozi as a conflict resolution model in Shona communities of Zimbabwe: a conceptual analysis. Critical African Studies, $11(2), 159-175$.

[12] Dukalskis, A. (2011). Interactions in transition: How truth commissions and trials complement or constrain each other. International Studies Review, 13(3), 432-451.

[13] Fischer, M. (2011). Transitional justice and reconciliation: Theory and practice.

[14] Galadima, H. S. (2006). Peace support operations in Africa. Introduction to peace and Conflict Studies in West Africa. Ibadan: spectrum Books Limited.

[15] Huyse, L., \& Salter, M. (2008). Tradition-based Justice And Reconciliation After Violent Conflict: Learning From African Experiences. Stockholm: International IDEA.

[16] Kasapas, G. (2008). An introduction to the concept of transitional justice: Western Balkans and eu conditionality. Revista UNISCI, (18), 59-76.

[17] Kritz, N. J. (Ed.). (1995). Transitional justice: how emerging democracies reckon with former regimes (Vol. 2). US Institute of Peace Press.

[18] Lai, D. (2016). Transitional justice and its discontents: Socioeconomic justice in Bosnia and Herzegovina and the limits of international intervention. Journal of Intervention and Statebuilding, 10(3), 361-381.

[19] Laplante, L. J. (2008). Transitional justice and peace building: Diagnosing and addressing the socioeconomic roots of violence through a human rights framework. The International Journal of Transitional Justice, 2(3), 331-355.

[20] Lederach, J. P. (1999). The journey toward reconciliation. Herald Press.

[21] Machakanja, P. (2010). National healing and reconciliation in Zimbabwe: Challenges and opportunities.

[22] Mani, R. (2002). Beyond retribution: Seeking justice in the shadows of war (pp. 47-48). Cambridge: Polity Press.

[23] Meernik, J. (2005). Justice and peace? How the International Criminal Tribunal affects societal peace in Bosnia. Journal of Peace Research, 42(3), 271-289.

[24] Mihr, A. (2012). Transitional justice and the quality of democracy-From democratic institution building to reconciliation.

[25] Mutisi, M. (2011). The abunzi mediation in Rwanda: Opportunities for engaging with traditional institutions of conflict resolution.

[26] Mutisi, M. (2012). Local conflict resolution in Rwanda: the case of abunzi mediators. Integrating Traditional and Modern Conflict Resolution Experiences from selected cases in Eastern and the Horn of Africa. Durban, South Africa: Accord, 41-74.

[27] Nagy, R. (2008). Transitional justice as global project: Critical reflections Third World Quarterly, 29(2), 275-289.

[28] Nettelfield, L. (2006). Courting Democracy: The Hague Tribunal's Impact in Bosnia-Herzegovina (Doctoral dissertation, Columbia University).

[29] Ndlovu-Gatsheni, S. J. (2012). Rethinking Chimurenga and Gukurahundi in Zimbabwe: A critique of partisan national history. African studies review, $55(3), 1-26$.

[30] Ndlovu-Gatsheni, S., \& Benyera, E. (2015). Towards a framework for resolving the justice and reconciliation question in Zimbabwe. African Journal on Conflict Resolution, 15(2), 9-33.

[31] Nwolise, O. B. C. (2005). Traditional models of bargaining and conflict resolution in Africa. Perspectives on peace and conflict in Africa. Ibadan: John Archers Publishers Ltd.

[32] Oomen, B. (2005). Donor-driven justice and its discontents: The case of Rwanda. Development and Change, 36(5), 887-910 
[33] Orentlicher, D. F. (2008). Shrinking the space for denial: The impact of the ICTY in Serbia. New York: Open Society Institute.

[34] Raddatz, R. (2012). 10 Tempering great expectations: Peacebuilding and transitional justice in Liberia. Transitional justice and peacebuilding on the ground: Victims and ex-combatants, 178.

[35] Simura, B., \& Mudimu, G. T. (2019). Consequences of Elitist Reconciliation in Zimbabwe and South Africa: A Comparative Study. J Soc Sci, 58(1-3), 1323.

[36] Teitel, R. G. (2000). Transitional justice. Oxford University Press on Demand.

[37] Wachira, G. (2017). The African Union Transitional Justice Policy Framework: Promise and Prospects.

\section{AUTHORS}

First Author - Ched Nyamanhindi is a PhD student at the Institute of Peace, Leadership and Governance (IPLG) at Africa University. He holds a Masters in Peace and Governance (Africa University 2013). Ched has keen interest in the areas of peace and security and transitional justice. 